\title{
Русины і їх путь до Чехословакії (1918-1919)
}

\begin{abstract}
Streszczenie
Rusini i ich droga do Czechosłowacji

Jako pierwszy wielki konflikt zbrojny w Europie w XX wieku, pierwsza wojna światowa dotknęła również tereny północno-wschodniej Słowacji oraz dzisiejszego Zakarpacia, a w ogromnym stopniu te wsie, w których żyli Rusini. Później, po wycofaniu się armii rosyjskiej, Rusinów tych oskarżano o jej wspieranie, w wyniku czego wielu z nich padło ofiarą prześladowań i represji ze strony węgierskiego rządu. Miało to potem niebagatelne znaczenie dla tego, jak Rusini postrzegali przyszłe losy zamieszkiwanych przez nich ziem. Gdy wojna dobiegła końca, Rusini rozważali kilka sposobów zmiany swojej sytuacji politycznej w Europie Środkowej. Z ich perspektywy istniały następujące możliwości: 1) Ruś Podkarpacka jako autonomiczny region historycznych Węgier, lub Republiki Węgierskiej; 2) Ruś Podkarpacka jako część cesarstwa rosyjskiego; 3) Ruś Podkarpacka jako część zjednoczonej Ukrainy; 4) Ruś Podkarpacka jako niezależne państwo; 5) Ruś Podkarpacka jako część państwa czechosłowackiego. Faktem stał się ten piąty wariant. Na podstawie traktatu z Saint-Germain z 10 września 1919 roku, terytorium Rusi Podkarpackiej stało się częścią Czechosłowacji, zachowując status autonomii.
\end{abstract}

Słowa kluczowe: pierwsza wojna światowa, Karpatorusini, cesarstwo austrowęgierskie, Węgry, Ruś Podkarpacka, Czechosłowacja, autonomia, Grigorij Žatkovič, Anton Beskid

1 Штудія $є$ скороченым і управленым текстом автора, публікованым в словацькім языку в зборнику Studium Carpato-Ruthenorum 2015. 


\begin{abstract}
Summary
Rusyns and Their Way to Czechoslovakia

The first great military conflict of the $20^{\text {th }}$ century in Europe, World War I, also affected the area of north-eastern Slovakia and present-day Transcarpathia and, to a great extent, those villages where Rusyns lived. These Rusyns were later, after the Russian army retreated, accused of supporting it and many were, thus, persecuted and victimised by the Hungarian government. That, later, played a considerable role in the way Rusyns thought of the future position of the territory they lived in. When the war ended, Rusyns considered several ways of changing their position in Central Europe. From their viewpoint, there were the following options: 1) Subcarpathian Rus as an autonomous part of historical Hungary, or Hungarian Republic; 2) Subcarpathian Rus as part of the Russian Empire; 3) Subcarpathian Rus' as part of a united Ukraine; 4) Subcarpathian Rus as an independent state; 5) Subcarpathian Rus as part of the Czechoslovak state. What came to pass was the fifth alternative. Based on the Treaty of Saint-Germain from September $10^{\text {th }}, 1919$, the area of Subcarpathian Rus became part of Czechoslovakia with autonomous status.
\end{abstract}

Key words: World War I, Carpatho-Rusyns, Austro-Hungarian Empire, Hungary, Subcarpathian Rus', Czechoslovakia, autonomy, Grigorij Žatkovič, Anton Beskid

\title{
Русины в Угорьску перед кінцём 1. світовой войны
}

Нашу статю зачнеме короткым історічно-геoграфічным поглядом на теріторію, на котрій в Угорьску жыло русиньске жытельство на переломі 19. і 20. стороча. Ішло о приближно 450000 жытелїв, што передставлёвало 2,7\% із цїлой кількости жытельства Угорьска. Русиньске жытельство жыло концентрованїше в Мараморошскій (46,7\%), Бережскій (48,2\%), Угочскій $(40,5 \%)$ і Ужскій жупі $(38,2 \%)$. В меншій кількости в Земпліньскій (11,6\%), Шарішській $(22,5 \%)$, в Спішскій $(9,4 \%)$, Бач-бодрожскій $(1,3 \%)$, Сатмарьскій $(0,4 \%)$ і Боршодьскій жупі $(0,1 \%)$.

Тоты даны наповідають, же в Угорьску жыло релатівно мало Русинів а зарівно тыж то, же Русины в мултіетнічнім штатї з оглядом на свою кількость не мали а ани не могли мати великый вплив на жывот ці на внутрополітічный розвой країны. Гірше але было, же Русины, як і другы 
немадярьскы народы і народности в Угорьску, были од другой половины 19. стороча выставлены все силнїшому мадярізачному натиску. Угорьскы - мадярьскы влады мали стратегічну амбіцію выбудовати з Угорьска єднонародный мадярьскый штат а з тых позіцій приступали к немадярьскому жытельству. В практічнім жывотї то значіло, же оклїщовали навчаня і выхову цїлых ґенерацій к іншій як мадярьскій културї і традіціям, оклїщовали навчаня немадярьскых народів в їх народных языках і выхову к їх властному народному усвідомлїню. То ся природно одзеркалило на збідачованю народных немадярьскых култур і на скоро нуловій едукації в народнім языку. Русиньска інтелігенція была у великій мірї змадярізована а аж на дакілько вынятків, переважно грекокатолицькых священиків, ся о піднятя свого народа барз не старала.

Далшов невыгодов Русинів было то, же переважно жыли в горьскых і підгорьскых областях Угорьска з мало уроднов землёв і з мінімалнов індустіалізаціёв, котра бы помогла Русинам економічно ся підняти. Фізічна біда была звязана з біднов културнов, едукачнов і народнов зрїлостёв русиньского жытельства.

Такы обставины примушовали Русинів глядати лїпшы условія про свій жывот, або ся холем выслободити із тяжкого соціалного поставлїня, до якого ся дістали цїлы їх генерації. Еміграція за роботов до Споєных штатів америцькых ся відїла быти можным рїшінём. На переломі 19. і 20. стороча з теріторії Угорьска одышло до США 100 аж 150 тісяч Русинів. Штатістікы о їх кількости не суть єднотны і правдоподобно ся бадателям не подарить їх уточнити, бо до кінця 19. стороча были вшыткы емігранты з Угорьска евідованы як Угры, а не подля їх скуточной народности. Многы, котрым ся на початку 20. стороча не подарило одыйти з Угорьска легално, приходили ілегално і на теріторію США, найчастїше з Канады, также і тоты припомогли к такій неточній евіденції русиньскых емігрантів. Фактом але зістає, же Русины в США ся пересвідчіли, же в демократічній країнї ся мож без страху і репресій голосити ід властній народности, учіти ся в народнім языку і розвивати народне усвідомлїня. Такым прикладом імм были Словаци, котры мали в США цїлый ряд краяньскых сполків, з котрыма ся знали, были їм близкы языком і менталітов, а про америцькых Русинів у многім ся стали іншпіратівным прикладом. Тым, же в США нашли роботу, хоць недобрї плачену, мали можность нашпорити сі фінанції, котры заганяли домів, або вдяка котрым за нима до США пришли їх найблизшы і в США зістали жыти. Із 
заробеных пінязей їх дїти в США могли здобыти нелем основну, але докінця і высокошкольску освіту. Просто, інакшы сполоченьско-політічны і економічны условія, в якых жыли передтым в Угорьску, в США дали америцькым Русинам можность розвивати народну свідомость, чутя гордости і незалежности. Кінцём рока 1918, кедь ся кінчіла Перша світова война, жыли і дїяли в США уж „інакшы” Русины, як на переломі 19. i 20. стороча, коли приходили до США, а ту ся удомашнёвали. Были то уж люде, котры хотїли быти актівныма і так помочі прінціпіално змінити сітуацію, в якій жыли їх краяне в Угорьску.

Статус русиньского жытельства в Угорьску ся в часї Першой світовой войны не змінив, але наспак, згіршыв ся. Ід едкономічному і народному утиску ся припоїло і підозріваня австро-угорьскых органів, армады і шандарїв із сімпатій к неприятельскій Росії і з помочі російскій армадї, котра на теріторію Угорьска (северовыходной Словакії і днешнёго Закарпатя) проникла кінцём септембра 1914 і потім зачатком рока 1915. По єй уступі за Карпаты в маю 1915 зачали великы перзекуції Русинів за конкретну і выдуману поміч російскій армадї в часї єй перебываня на теріторії Угорьска.

Екстремны перзекуції привели дакотрых грекокатолицькых священиків к зорганізованю народной громады в Нижнїм Верецькім в Свалявскім окресї, выслїдком котрой была петіція адресована угорьскій владї із жадостёв, жебы была зрушена назва „русскій” - „Русь”, і была замінена назвов „Мадяр” або „католик выходного обряду”. Была то на першый погляд абсурдна жадость, яка мала одвернути підозріня русиньского жытельства з велезрады уж лем з той прічіны, же їх назва звучала в мадярьскім языку „Orosz” - „Рус”. Хоць назва русиньского жытельства зістала в Угорьску і дале єднака, такы ініціатівы лем підпоровали далшы крокы угорьской влады проти Русинам з цїлём їх поступной асімілації.

Єдным із такых кроків была жадость міністра школства і церькви Белы Янковіча (1865-1939), котрый ся обернув на представителїв Мукачевской, Пряшівской і Гайдудорожской єпархії із жадостёв на заведжіня грегоріаньского календаря, ліквідацію кірілікы і повне вжываня латинікы з мадярьсков транскрібціёв. Главна грекокатолицька комісія в Будапештї одобрила план переходу на латиніку і грегоріаньскый календарь, контролёв повірила Карла Клебелсберга, таёмника міністерства, і пряшівского єпіскопа Штефана Новака (1879-1932). Но тот план 
натрафив на нечеканый одпор низшого клеру, зато мукачевскый єпіскоп Антоній Папп (1867-1945) одсунув зміны аж на рокы 1916/1917. (Pop 2005, 271).

Єпіскоп Пряшівской єпархії Штефан Новак ініціовав выдаваня нового тыжденника Nase otecsesztvo (1916-1919). Ёго главнов задачов было пропаговати латиніку і вірность грекокатолицькій церькви і великому Угорьску. Приклад Новака наслїдовав і мукачевскый єпіскоп Антоній Папп.

До кінця Першой світовой войны будапештьска влада немілосердно карала каждый прояв народной свідомости Русинів, причім ся намагала невтралізовати русинство і русофілство. То была прічіна, чом зачала підтримовати україньскый націоналізм галічского тіпу. В роцї 1916 ту быв основаный часопис Украіна і заказаный русиньскый часопис Наука. Задачов редакції часопису Украіна было пропаговати ідею україньского штату, котрый ся подля поглядів мадярьскых політіків мав стати буфернов зонов меджі Росіёв і Русинами в Угорьску. Тоты ініціатівы Будапешта были в згодї з нїмецьков підпоров сепаратістічных тенденцій Українцїв, котры ся хотїли дістати спід влады Росії - царьской і демократічной (по фебруаровій револуції 1917), но тыж большевіцькой по большевіцькій револуції в новембрї 1917 (октобрї подля юліаньского календаря) і створити свій властный штат.

Русины аж до кінця першой світовой войны не мали выяснены свої штатотворны пожадавкы. Їх малочісленна інтелігенція была у великій мірї помадярчена (грекокатолицьке духовенство, учітелї, правници, урядници), а так до войны і протягом нёй ся ани не занимали можностями прінціпіалной трансформації Угорьска і статусу Русинів у нїм.

\section{Алтернатівы штатоправных змін у статусї Русинів}

Першы увагы о штатоправных змінах і статусї угорьскых Русинів ся од половины 19. стороча появили аж в роцї 1918, а то в часї, кедь было ясне, же монархія не буде по скінчіню войны таков, яков была на єй зачатку. Правда, Русины, котры жыли дома, не знали о змінах, якы ся в контекстї Австро-Угорьска рихтують, респ. не чекали, же засягнуть i їх. Русины, котры жыли в еміграції, головно в США, і котры мали значно веце інформацій, не знали котры 3 назначованых можностей бы ся 
могли зреалізовати. Каждый собі усвідомлёвав, же до увагы приходило дакілько варіантів штатоправного статусу русиньского жытельства по скінчіню войны. Дакотры были реалны, другы мали скорїше теоретічній характер. Были то слїдуючі алтернатівы:

1. Підкарпатьска Русь як автономна часть Угорьска, респ. Мадярьской републікы;

2. Підкарпатьска Русь як часть російской імперї;

3. Підкарпатьска Русь як часть зъєдноченой Україны;

4. Підкарпатьска Русь як незалежный штат;

5. Підкарпатьска Русь як часть чехословацького штату.

\section{Угорьска (Підкарпатьска) Русь як автономна часть Угорьска, респ. Мадярьской републікы}

Слїдуючі роздумованя домашнї Русинів, было видно, же алтернатіва автономного статусу Угорьской Руси в зреформованім Угорьскім кралёвстві, респ. в демократічнім Мадярьску была про русиньску інтеліґенцію і формуючу ся політічну гарнітуру найреалнїшов. Не выжадовала нияку револуцію, ниякый озброєный конфлікт, якый бы еліміновав угорьску - мадярьску справу і брахіалну міць репрезентовану так поліціёв, як і армадов. Окрем того ся могла операти о выголошіня новых репрезентантів політічной моци в Будапештї, на челї котрых стояв лібералный мадярьскый політік Мігай Карої (1875-1955), котрый в новембрї 1918 выдав вызву ід вшыткым народностям Угорьска в їх языку, жебы заховали Угорьско, не розрывали го, і дав їм можность справовати свої дїла в їх народнім языку. Вызва зачінала словами: Ід каждому немадярьскы бісїуючому народу слободной републікы! Словаци, Нїмии, Румуны, Русины, Сасы, Сербы!!... Каждый народ на своій теріторії, у своій століиї, окресї, селї няй сам вырішить, в якім языку ся хоче учіти, із своїм рыхтарём, нотарём бісїовати...

Нова мадярьска влада давала немадярьскым народностям і релатівно щіры можности, Русинам автономію в губернії, яку назвала Руська Крайна. При каждій народности докінця выберала термінологію, котра мала быти близка традіції даной народности і єй языку. Зато Русинам пропоновала автономну губернію - самосправный цїлок названый подля російскых адміністратівно-справных цїлків, хоць 
угорьскы Русины у своїй історії нїгда нияку губернію і губернатора не мали. Подобно то было і з назвов Руська Крайна, што мало сімболізовати стары адміністратівны цїлкы середнёвічного Угорьска - крайны - крайнї теріторії, якы угорьскы владарї формовали на своїх северных граніцях як буферны зоны із цїлём хранити країну перед вонкашнёв загрозов, а таков крайнов - буфернов теріторіёв была тогды і теріторія Угорьской Руси.

Із наростаючов загрозов розпаду Угорьска мадярьска влада 21 децембра 1918 прияла закон ч. Х, на основі котрого створила русиньску автономію Руську Крайну. Зачатком рока 1919 мадярьска влада іщі спробовала утримати теріторію Підкарпатьской Руси выданём наряджіня ч. 928 з 5 фебруара 1919, яке выходило із закона ч. X, а про Руську Крайну установила владу. На єй чело выменовала Др. Ореста Саба, котрый ся став сучасно і міністром Руськой Крайны при мадярьскій владї. Выголосила і вольбы до русиньского сейму, і 4 марца 1919 ся вольбы одбыли на теріторії, котра не была обсаджена чехословацькым войском. На вольбы пришло барз мало волічів. Переважна часть русиньского жытельства або о них не знала, або їх уж не акцептовала. 5 марца 1919 было до Мукачева скликане засїданя зволеного сейму, котрый мав 36 членів. Мадярьска влада ся надїяла на ёго лоялность з Мадярьском. Засїданя сейму вів губернатор Руськой Крайны Августин Штефан. На засїданю взяв участь і міністер Др. Орест Сабо, котрый ту передставив програм влады і чекав, же буде приятый.

Про Русинів то значіло реалны крокы мадярьской влады к акцептованю їх потреб, а навыше, і з гаранціёв стабіліты тых позіцій, котры занимали ведучі русиньскы представителї в різных сферах сполоченьско-політічного жывота. По попереднїх десятьрочах несправедливостей к Русинам, новы пропозіції Будапешта значіли величезный прогрес про них.

5 новембра 1918 ся зышла громада русиньской інтелігенції в Ужгородї, де з одобрїнём єпіскопа Антонїя Паппа зволили шпеціалный выбор. На ёго челї стояв Августин Волошин (1874-1945). Выбор скликав на 9 новембра 1918 народну громаду, на котрій была створена Угроруська народна рада. Канонік Сімеон Сабов (1863-1929) быв зволеный за председу a А. Волошин за секретаря. На громадї участници прияли меморандум, в котрім підпорили інтегріту мадярьского штату, але зарівно жадали про Русинів такы права, якы будуть мати і другы народы того штату. Окрем 
того, жадали автономну справу грекокатолицькой церькви, выбудованя катедры руського языка на будапештьскій універзітї і господарьскы реформы (Švorc 1996, 17). Безодкладно зачали діскутовати о своїх жадостях з мадярьсков владов. В Будапештї о них говорив Сімеон Сабов з Мігаём Кароём, Мартіном Ловасом і Оскаром Ясом (1875-1957), котры му приобіцяли сповнити вшыткы предложены жадости.

Мадярьска влада, яка хотїла утримати ініціатіву Русинів під контролёв, дала імпулз на створїня Руськой народной радь в Будапештї (Šandor 1992, 188) і повірила Др. Ореста Саба задачов - приправити автономію Руськой Крайны. На 10 децембра 1918 скликав Орест Сабо до Будапешта народну громаду угорьскых Русинів, на котру мала прийти лем лоялна, проугорьска русиньска інтелігенція. На громадї была настолена жадость інтегріты Мадярьска, а про Русинів створїня шпеціалной русиньской губернії з центром у Мукачеві і створїня русиньского міністерства.

Народна громада в Будапештї але не была єднотна, затоже на нїй брали участь і такы, котры были проти того, жебы Угорьска Русь была частёв мадярьского штату. Із крітіков жадостей на утриманя інтегріты Угорьска выступили делегаты з Хусту Др. Юлій Бращайко, Юлій Чучка, Петро Долинай, Штефан Клочурак і другы, котры, на противагу, у своїй пропозіції жадали припоїти Підкарпатьску Русь к Українї, і їх пропозіція здобыла підпору делегатів. Наперек тому выбор громады запропоновав резолуцію, в котрій ся говорить, же угроруськыцй народ зістане вірныцй своїм тісячрічным традічіям і отчізнї, і жадать незалежность свого народного жьвота од мадярьского народа посередництвом гараниіі автономных прав (Tvoridlo 1922, 43). Лемже таку жадость громада не прияла і жадала, жебы народна громада проходила на властній теріторії, а не на чуджій - в Будапештї. Презідія мала скликати нову громаду 21 януара 1919 в такім містї, о котрім вырїшить векшына.

Сітуація в середнїй Европі ся швыдко мінила, 28 октобра 1918 быв у Празї выголошеный чехословацькый штат. Ёго влада войском і діпломатічнов путёв поступно обсаджовала теріторію Словакії а в яри 1919 уж і теріторію бывшого Угорьска, на якій жыло русиньске жытельство, знаючі, же ся стане частёв ЧСР. Значіть, же частёв ЧСР ся стала нелем северовыходна Словакія, але і Угорьска Русь, яка в новім штатї дістала назву Підкарпатьска Русь. На основі того і проугорьскы орьєнтованы русиньскы кругы ся помалы зачали орьєнтовати на другы можности, 
і уступили од мадярьской/угорьской алтернатівы. Їх рїшіня ускорило выголошіня Мадярьской републікы рад в марцу 1919, котрой ся як комуністічной бояло головно грекокатолицьке духовенство.

Америцька русиньска еміграція, так як і словацька, была під сталов контролёв австро-угорьскых діпломатів. Тото од міністерства загранічных дїл Австро-Угорьска жадав Будапешт уж од кінця 19 стороча, жебы робітници амбасады і конзулатів у США регуларно інформовали о актівітах угорьскых славяньскых емігрантів. К русиньскым грекокатоликам потім Будапешт высылав грекокатолицькых священиків, якы мали віруючіх вести ід любви к угорьскій отчізнї. Якраз з такого середовища русиньскых грекокатолицькых священиків выходило найвеце сімпатізантів інтегріты Угорьска а єдинов змінов, яку были охотны акцептовати, была русиньска автономія в рамках великого Угорьска. Зато ся одперали од будьякых іншых штатотворных алтернатів, котры взникали в рамках русиньскых краяньскых організацій, респ. в редакціях краяньскых новинок.

Веджіня Греко-католическаго объединения в США підтримовало Угорьско і часть єрархічно высшых грекокатолицькых священиків в марцу 1918 на стрїчі в америцькім містї Мек-Кіспорт (Пенсілванія) приготовила резолуцію, з котров ся обернули на угорьскых грекокатоликів в США, жебы зістали вірныма Угорьскому кралёвству. В далшых місяцях ся у веджіню Греко-католическаго объединения зачав погляд на будучность Русинів в Угорьску значно діференцовати. На XV зъяздї Греко-католическаго объединения 9-22 юна 1918 в Клівлендї (Огайо) і Бреддоку (Пенсілванія) проугорьскы орьєнтованы священици ініціовали одкликаня Николая Пачуты з функції председы сполку і під їх впливом зъязд вырїшив, же Русины, якы походять з Угорьска, ся будуть означовати як „Угро-Русины” жебы ся одлишили од галічскых.

23 юла 1918 ся в Гомстедї (Пенсілванія) зышли представителї Сoединения греко-католических русских братств і Собрания греко-католических церковных братств і створили Америцьку народну раду Угро-Русинів (Американская народная рада Угро-Русинов). Тота ся выголосила за єдиного репрезентанта Русинів Угорьска і в тзв. Гомстедьскій резолуції підтримали автономію Угорьской Руси в Угорьску. Над Чехословакіёв не роздумовали, а то з оглядом на можны конфлікты із Словаками про Земпліньску, Шарішску, Абовску, Спішску і Ужску жупу (Рор 2005, 273-275). 


\section{Підкарпатьска Русь як часть російской імперії}

Тота алтернатіва ся зродила в русофільскых кругах Русинів жыючіх в северовыходній Словакії і головно в Пряшові. Выходила з традічного русофілства русиньской інтелігенції і операла ся о можность тріумфу Росії у войнї, обсаджіня і припоїня Галічі к російскій імперії, чім бы ся Росія теріторіялно приближыла аж к граніцям Угорьска, а перекрочінём Карпат, што ся двараз у войнї і стало, бы ся частёв імперії стала і теріторія заселена угорьскыма Русинами. Правда, в роцї 1918, кедь уж большевіцька Росія підписала в Брестї-Літовскім сепаратный мір з Нїмецьком і Австро-Угорьском і перестала боёвати, така можность стратила логіку. За думков припоїня теріторій заселеных Русинами стояв главно правник Антоній Бескид (1855-1933), котрый але не інкліновав к большевіцькій Росії, зато думка припоїти теріторію заселену Русинами к російскій імперії іщі курто выходила з представы перемогы білогардійскых войск в обчаньскій войнї, котра ся в Росії розшырила, і о екстеріторіялность Угорьской Руси в одношіню к російскій імперії. В теоретічнім планї бы мала быти їх теріторія домініёв Росії, так як то было напр. з Австраліёв ці Канадов в одношіню к Великій Брітаніі.

Думку припоїти Угорьску Русь к російскій імперії дуже курто інштітуціонално репрезентовала Руська народна рада (РНР), яка взникла 21 децембра 1918 споїнём пряшівской РНР із старолюбовняньсков РНР, знамов під назвов Рада Лемків.

Ідея споїти теріторії заселены Русинами з російсков імперіёв мала своїх сімпатізантів і меджі америцькыма Русинами.

13 юла 1917 ся в Ню Йорку одбыв Русиньскый конгрес (Русскій конгрес), якый організовали русофільскы орьєнтованы емігранты із Галічі, Буковины і Угорьской Руси. Галічскых Русинів репрезентовав Петро Гаталак а угорьскых Николай Пачута, председа Америцько-руськой [русиньской] народной обороны (Американско-русская народная оборона) і председа Грекокатолицького соєдинїня (Греко-католическое объединение) (Рор 2005, 272).

Конгрес хотїв Прикарпатьску Русь зложену із Галічі, Угорьской Руси і Буковины зъєдьнити з демократічнов Росіёв, што ся іщі відїло як реална ідея. В тім часї было царьске самодержавіє вже минулостёв і міць была в руках Дочасной влады. Така жадость америцькых Русинів, декларована в меморандумі конгреса і послана представителям штатів Догоды, 
выкликала найперше одпор брітьскых діпломатів в США, але наслїдно і русиньской грекокатолицькой церькви в США. Тота жадала автономію в рамках Угорьска. Лемже большевіцькый переворот в новембрї 1917 таку алтернатіву в русиньскых штатотворных увагах навсе поховав.

\section{Підкарпатьска Русь як часть зъєдноченой Україны}

Думка, жебы ся угорьскы Русины стали частёв Україны, ся операла о взник україньского штату, а ідейно о приятя україньской културной і етнічной орьєнтації частёв русиньской інтелігенції. Была повязана з роком 1918, коли в януарї 1918 была выголошена Україньска народна републіка.

Єй выголошіня привітали Українцї жыючі в Галічі. В септембрї 1918 взникнув у Львові воєньскый выбор а на зачатку октобра было сформоване політічне веджіня з різных політічных партій, якы ся мали приготовити на перевзятя моци у выходній Галічі.

18 октобра 1918 ся зышли україньскы політіци і репрезентанты общественного жывота у Львові, де зволили Україньску народну раду як політічного репрезентанта Українцїв Австро-Угорьска. В тот самый день выдали декларацію, в котрій увели, же Галіч, Лемковина, северозападна Буковина і україньскы теріторії северовыходного Угорьска будуть належати до сполочного україньского штату.

Сучасно рїшали вопрос споїня того штату з Украӥньсков народнов републіков - гайтманатом, яка єствовала уже помалы рік. По довгых діскузіях ся договорили, же не будуть жадати споїня обидвох україньскых штатів, бо ся бояли того, же по скінчіню войны зачнуть платити Вілсоновы пожадавкы на мір, в котрых америцькый презідент в пунктї VI вызнавав право Росії становити собі свій властный політічный розвиток і не говорив о можностях єй роздїлїня. Наспак, в пунктї X жадав якнайслободнїшый автономный розвой вшыткых народів Австро-Угорьска. Бояли ся, же внаслїдку споїня з выходнов Українов і нероздїлїня Росії може і Галіч зістати частёв російской імперії (Švorc 1999, 172). Окрем того галічскых Українцїв мотівовала к выголошіню самостатного штату польска ініціатіва. Поляци створили 28 октобра 1918 ліквідачну комісію, яка переберала в Галічі справу під себе. Меджі галічскыма Українцами і Поляками зачали взникати озброєны конфлікты. Україньскы воєньскы оддїлы 
1 новембра обсадили Львів і 9 новембра ту была выголошена Западоукраӥньска народна републіка (Polonska-Vasylenko 1988, 772). Председом влады ся став Кост Левицькый.

Хоць веджіня Западоукраїньской народной републікы первістно не уважовало о споїню зо Скоропадьского гайтманством (Україньсков народнов републіков), сітуація єй занедовго принутила змінити погляд Польскы войска 22 новембра обсадили Львів а україньска влада ся мусила перестяговати найперше до Тернополя а занедовго до міста Станїслав. У безвыходній сітуації зачала вести діскусії з Директоріёв Україньской народной републікы а 1.12.1918 делегація штатного секретаріату Западоукраїньской народной републікы підписала з Директоріёв договор о споїню обидвох републік до єдной Украӥньской народной републікъь. Лемже в роцї 1919 стратила єй директорія контролю над Українов, де наступила цїлкова анархія. Директорія в прінціпі не была способна помочі галічскым Українцям і Русинам протїв польскым жадостям. Од кінця рока 1918 была Западоукраїньска народна републіка в неперестанній войнї з Польщов о выходну Галіч, яку Поляци брали як стару польску теріторію і не хотїли Русинів акцептовати як самостатный народ. Під справов директорії на челї з Симоном Петлюром в яри 1919 была уж лем мала теріторія на югозападі Україны, а як ся споїла з Поляками, стратила підпору галічскых Українцїв (Kappeler 1994, 180).

В часї, коли ся іщі вказовали можности на самостатну екзістенцію Украйньской народной републікы, угорьскы Русины цалком логічно зачали зважовати алтернатіву припоїти ся ід ній. 8 новембра 1918 на громадї Русинів із Спіша і Шаріша на Старолюбовняньскім градї была з ініціатівы Еміліяна Невицького основана в прінціпі перша Руська народна рада (Рада Лемків), а тота ся прихылила к україньскій штатотворній орьєнтації. В тот день выдала декларацію, в якій підтримовала право народів на самоідентіфікацію в їх етнографічных граніцях, і зарівно одверьгла ініціатівы, котры бы мали Русинів роздїлити до різных штатных формацій. Якубяньскый священик Михал Михаліч попросив участників зробити народну збірку на бой за ослободжіня народа і сам дав першых тісяч корун: Няй міліоны выростуть з той скромной гривны даной на то, жебы наш русиньскый народ міг допомочі здобыти слободу. Вызыьвам тя, русиньскый народе: Од Любовнї аж по Сіготь до святого боя за слободу! (Tvoridlo 1922, 42). Еміліян Невицькый, Михал Михаліч, Йосиф Рыбовіч, Петро Шіма, Іван Мурцко, Іван Чанда, Др. Еміліян Тороньскый, 
Др. Николай Завадьскый і дакоты далшы представителї русиньской інтелігенції в слїдуючіх днях закладовали в русиньскых селах на Спішу, в Шарішу і северовыходнім Земплінї містны народны рады. Ініціатіву за припоїня русиньскых теріторій к Українї проявляв передовшыткым Е. Невицькый. У своїх проголошінях ясно жадав зъєдночіня угорьскых Русинів з великов Українов. Писав: Карпатьска Русь подає руку братам з Галічі і Буковины і зъєдночує ся з матїрёв руськых міст, із славным Києвом. Няй ся украӥньска земля стане одднесь і нашов... (Tvoridlo 1922, 20).

Кедь ся в децембрї 1918 споїла Рада Лемків з пряшівсков РНР, быв Еміліян Невицькый, вєдно з ёго ініціатівов припоїти теріторії заселены Русинами к Україньскій народній републіцї, одсунутый боком.

О ураїньскій орьєнтації незалежно од старолюбовняньской РНР уважовали і представителї русиньской інтелігенції з выходных частей Угорьской Руси. 8 новембра 1918 ся одбыла велика народна громада в Ясинї, яка підпорила жадость сформуловану Штефаном Клочураком, жебы ся Підкарпатьска Русь припоїла к Українї (Chymynec 1983, 21).

Кедь 17 новембра 1918 взникла в Хустї Руська (україньска) народна рада на челї з Юліём Бращайком, высловила ся за Україньску народну републіку. Тоту жадость предложыв єй председа Юлій Бращайко і на народній громадї Русинів 10 децембра 1918 в Будапештї а повторно была настолена 21 януара 1919 на великій народній громадї в Хустї. Ту собі 420 делегатів выбрало репрезентантів, якы мали діскутовати в Києві з репрезентантами Україньской народной републікы о припоїню Підкарпатьской Руси (Švorc 2007, 43).

Позіція Україньской народной републікы ся неперестанно компліковала, нова Польща не акцептовала Україну главно на теріторіях, якы брала за історічно польскы, большевіцькы войска обсадили єй выходну часть і боёвали з польскыма, а в роцї 1919 ся на міровій конференції в Паріжу уже інтензівно діскутовало о припоїню Угорьской Руси к Чехословакії. В такій сітуації были планы на причленїня Русинами заселеных теріторій до україньского штату нереалны.

\section{Підкарпатьска Русь як незалежный штат}

Алтернатіва незалежного русиньского штату была жыва меджі америцькыма Русинами, котры собі знали таку алтернатіву і представити, 
бо вдяка своїм скушеностям і довірї к властным силам, котры здобыли Америцї, вірили, же будуть способны самы справовати свій штат.

Были то русиньскы емігранты, котры до США приходили од 80-ых років 19. стороча до року 1914 , коли зачала война і еміграція ся заставила. В США жыло подля неофіціалных штатістік 130 000-155 000 Русинів із северовыходной Словакії і Угорьской Руси (Švorc 2003, 92), П.Р. Магочій говорить докінця аж о 225000 Русинах, але без точнїшой ідентіфікації теріторій, з котрых тоты емігранты пришли до США (Magocsi 1999, 379). Без огляду на то, ішло о значну масу людей з уже єствуючім і розвиваючім ся народным усвідомлїнём а тыж з даякым економічным потенціалом. Усїли ся в промысловых центрах США (Magočij 2006, 61-63), де закладовали краяньскы сполкы главно на грекокатолицькій конфесіоналній базї, выдавали краяньскы новинкы і часописы а до часу, коли ся перед войнов вертали домів, пробуджали і народне усвідомлїня своїх краянів дома (Magocsi 1994, 149).

У такім контекстї ся зродила і думка створїня незалежного русиньского штату. Но тота была настолена аж в осени 1918 попри іншых алтернатівах, о котрых америцькы Русины діскутовали од зачатку рока 1918.

Находиме єй експліцітно сформуловану в меморандумі Америцькой народной рады Угро-Русинів з назвов Memorandum from the American National Council of Uhro-Rusins, to his Excellency Woodrow Wilson, president of the United States of America (VHA fond P. R., k. N. 1, R. 245, 1918-1920).

B меморандумі была найперше описана теріторія, на якій Русины жыють, потім наслїдовала характерістіка Русинів як народа, америцькой русиньской еміграції з пописом єй дїятельства а наостаток была представлена пропозіція на рїшаня штатоправного статусу Русинів. Тот мав три варіанты. Першы два про Русинів жадали окрему штатну формацію:

1. Жебы угорьскы Русины дістали повну незалежность. Кедь то не буде можне, жебы ся - 2. могли зъєдинити з Русинами з Галічі і Буковины і створили сполочный штат. А кедь ани то не буде можне - 3. жебы здобыли якнайбівшу автономію в припадї, же Угорьска Русь зістане і дале частёв Угорьска. (VHA fond P. R., k. N. 1, R. 245, 1918-1920)

Жадость сформулована в 1. пунктї выходила 3 представы о штатї 3 назвов Угрорусинія, котрый мав заберати теріторію Угорьской Руси і цїлой выходной Словакії. Дакотры Русины были пересвідчены, же 
выходна Словакія была первістно заселена Русинами а аж наслїдно Словаками, котрыма были Русины асімілованы.

Жадость декларована в 2. пунктї выходила з представы о великім русиньскім штатї з назвов Карпатьска Русь, до котрой бы належала Угорьска (Підкарпатьска) Русь, северовыходна Словакія, Буковина і Галіч.

Меморандум указовало смілость америцькых Русинів і їх волю будовати свій штат, но не їх політічну вырзїтость і орьєнтацію в меджінародній сітуації в світї і в Европі. В часї, коли жадали незалежный штат, была вже середня Европа у великій мірї роздїлена і были прияты кулоарны рїшіня о тім, як ся буде по скінчіню войны формовати. Чехословацька і польска еміграція мала уж давно створены ясны представы о будучности своїх народів і о подобі їх штатных формацій, з котрыма не корешпондовали планы Русинів о незалежности. Тото русиньскій делегації высвітлив і америцькый презідент Вудров Вілсон, кедь їм повів, же не мож буде реалізовати першы дві жадости а же ани США їх реалізацію не підтримають. Їх увагу обернув на то, же мож реалізовати скоріґовану третю алтернатіву, а то автономію Підкарпатьской Руси, респ. Угро-Русинії, але не в мадярьскім штатї, але в дакотрім сусїднїм славяньскім штатї. В прінціпі назначів можность зачленїня той теріторії до приправлёваного чехословацького штату, а русиньскій делегації порадив глядати можности на споїня із сусїднїма славяньскыма народами (Žatkovič 1921, 1).

Внаслїдку того в прінціпі заникла алтернатіва незалежного русиньского штату а штатотворны планы америцькых Русинів ся заміряли уж лем на єдину реалну алтернатіву - зачленїня їх теріторії до приправлёваного чехословацького штату.

У тім котекстї можеме іщі спомянути пробу Русинів предложыти пропозіцію незалежной Карпатьской Руси міровій конференції в Паріжу зачатком рока 1919, котру приправив Антоній Бескид. Бескидова Карпатьска Русь заберала северны области Спішской, Шарішской і Земпліньской жупы, Ужску жупу і теріторію цїлой Угорьской Руси, враховано цїлой Мараморошской жупы, котра пізнїше была роздїлена а єй южна часть припала Румунії. Выходячі з контексту Бескидовых актівіт од зачатку рока 1919 (з ёго комунікації із Словацьков народнов радов у Мартінї, зо стрїчі з уповномоченым міністром про справу Словакії Вавром Шробаром 11 януаря 1919 в Пряшові і з ёго рекомендації, жебы ся А. Бескид выбрав до Прагы і там реферовав о позіції містной Руськой народной 
рады (Пряшівской) і як репрезентант угорьскых Русинів одышов до Паріжа на мірову конференцію (Švorc 2012, 49)), можеме предпокладати, же предложена мапа при єй зродї презентовала Карпатьску Русь як представу Русинів о подобі автономной країны в рамках Чехословакії а лем під впливом І.І. Жатковіча ся перетрансформовала на жадость о окремій штатній формації, і то правдоподобно лем як даяка форма натиску Русинів на владу ЧСР, жебы решпектовла факт, де всягды Русины у взникаючій Чехословакії жыють.

Ід групі штатотворных візій о окремій штатній формації угорьскых Русинів належить і епізодічна екзістенція Гуцульской републікы. Тота была выголошена на теріторії в околіцї Ясинї а за председу єй влады быв зволеный Степан Клочурак, котрый командовав озброєній групі із скоро тісяч вояками. Веджіня Гуцульской републікы перешло до ілегаліты, кедь дав новый председа мадярьской влады М. Карої 22 децембра 1918 обсядити теріторію выходной части Мараморошской жупы.

7-8 януара 1919 выбухло в Ясинї озброєне повстаня, цїлём якого было зліквідовати мадярьску справу. Была обновлена Гуцульска републіка а з ініціатівы председы Мараморошской народной рады Михайла Бращайка гуцульска міліція напала на мадярьске войско в долинї рїкы Тисы і обсадила так Мараморош-Сігет і Великый Бычков (Рор 2005, 281-298).

Но 19-20 януара 1919 румуньскы войска вытисли гуцульскы міліції аж до ясиньской котлины а кедь 11 юна 1919 обсадили цїлу Мараморошску жупу, Гуцульска републіка заникла а єй теріторія была в септембрї 1919 на основі Сенжерменьского договору припоєна к Чехословакії.

Главны актеры Гуцульской републікы были україньской орьєнтації a їх первістным заміром было теріторію заселену Русинами припоїти к Українї. Они самы Гуцульску републіку відїли лем як дочасну штатну формацію.

\section{Підкарпатьска Русь як часть чехословацького штату}

Про Русинів алтернатіва чехословацького штату стояла на послїднїм місцї. Выходило то з дакількох фактів:

а) домашня політічна сцена ся прагматічно орьєнтовала на найпростїшу алтернатіву - на Угорьско з русиньсков автономіёв, 
б) невыясненость етнічных граніць меджі Русинами і Словаками і історічнов адміністратівно-справнов базов тых жуп, в котрых жыли обидва народы, сігналізовали конфлікты меджі двома, до розпаду Австро-Угорьска єднако утискованыма, славяньскыма народами. Што до кількости слабшы Русины собі усвідомлёвали граніцї своїх можностей кедь претендовали на выходословацькы жупы, а усвідомлёвали собі і то, же без помочі міцнїшого партнера (Будапешта, Львова, респ. Києва, Москвы) не будуть способны здобыти уведжену теріторію під свою, хоць автономну, справу.

Но події ся розвивали так, же і наперек уведженым детермінантам в увагах Русинів дома і в еміграції, поступно, незалежно од Русинів, міцнїла лем єдна алтернатіва, котра мала надїю на успіх - чехословацькый штат.

Чехословацька алтернатіва зачала доміновати меджі Русинами найперше в США, а то у звязи з їх першыма знамыма діскусіями о судьбі теріторії, на котрій в Угорьску, респ. Австро-Угорьску Русины жыли. Діскусії ся зачали спорадічно вести іщі в роцї 1917, кедь быв на Руськім (русиньскім) конгресї в Ню Йорку отвореный вопрос будучности Русинів. Чехословакія як алтернатіва ту тогды іщі не была настолена, доміновали другы (высше уведжены) алтернатівы, котры непрямо підпорило зачатком рока 1918 і выголошіня америцького презідента В. Вілсона, якый в декларації Конгресу США настолив 14 пунктів мірового програму, причім десятый пункт говорив лем о автономії про народы Австро-Угорьска (Švorc 1991, 74-76).

Русофіл Николай Пачута, як председа двох вызначных русиньскых обществ в США по тім, як ся російска алтернатіва указала нереална і неактуална, зачав вести діскусії з америцькыма Словаками о зачленїню Угорьской Руси до будучой Чехословакії. А таку можность предложыв в апрілю 1918 і штатному таёмникови США Робертови Ленсінгови (Рор $2005,274)$. О місяць пізнїше - кінцём мая 1918, меморандум з жадостёв причленити Русинів к чехословацькому штату предложыв Т.Г. Масарікови, котрый ту пришов з Росії і стрїтив ся з Чехами і Словаками, а 30 мая 1918 з представителями найвызначнїшых краяньскых організацій - Словацькой лігы, Чеського народного здружіня і Союзу чеськых католиків (Slovenská liga, České národní sdružení, Svaz českých katolíků) сформуловав і підписав договор, котрый до історії вступив як Пітсбурьскый договор (Kucík a Švorc 2014, 65-87). 
Т.Г. Масарік в тім часї іщі не быв готовый ани особно, ани в менї чехословацького одбоя ся завязати обіцянками, котры не міг гарантовати, а о то веце, кедь відїв, же за Пачутом не стоїть ани бівша часть русиньской еміграції, ани єй організації.

Меморандум (VHA fond P. R., k. N. 1, R. 245, 1918-1920), котрый на основі повірїня Америцькой угроруськой народной рады выготовив І. І. Жатковіч і котрый америцькы Русины передали В. Вілсонови, не были прияты до концепції европской політікы штатів Догоды, о чім Русинів інформовав америцькый презідент. Так Русинам зістала лем чехословацька алтернатіва, котру америцькы Русины обходили, бо ся не хотїли дістати до конфліктів зо Словаками односно теріторії выходословацькых жуп.

Конфлікт, котрый ся зачав рісовати, ся не дотуляв дакількох сел або лем малой теріторії, але дотуляв ся пятёх комітатів - Спіш, Шаріш, Земплін, Абов і Гемер, котры Словаци поважовали за словацькы, ці переважно словацькы, а на котры претендовали і Русины. Но в США жыла міцна комуніта Словаків якраз з выходной Словакії, котра не уважовала о тім, же бы села, одкы походили, мали належати до іншой штатной формації як словацькой ці чехословацькой, але в ниякім припадї не до русиньской (Švorc 2003, 92-108).

То была і головна прічіна, чом америцькы Русины зачали діскутовати з Масаріком, хоць репрезентуючім чехословацькый одбой, но в звычайнім розуміню передовшыткым чеськый одбой. Масаріка несподївали русиньскы жадости, но як добрый діпломат на них не реаговав прямо. Надїяв ся на далшый розвиток сітуації, од котрого чекав ослаблїня рісуючого ся конфлікту. Но треба підкреслити, же про Масаріка, як і про цїлу чеську політіку, мала Словакія векшу пріоріту як Угорьска Русь а то была і прічіна, чом Чехы а конкретно і Масарік преферовав словацькый інтерес перед русиньскым. 3 другого боку, Масарік не хотїв стратити ани шансу на збівшіня чехословацького штату о Угорьску Русь, о то веце, же ішло о близкый славяньскый народ.

Жатковіч предложыв Масарікови копію меморандума, котру 21 октобра 1918 передали Вілсонови, а тот сі на єй край пером позначів: S Žatkovičem a jeho prátely ve Philadelphii raději, obšírně 26. oct. 1918 o možnosti jejich připojení k našemu státu. Dají návrh (VHA fond P. R., k. N. 1, R. 245, 1918-1920).

23 октобра 1918 была Америцька народна рада Угро-Русинів прията за члена Середнёевропской демократічной унії (Mid European Democratic 
Union), на челї котрой стояв Т.Г. Масарік. Жатковіч, як єден із представителїв дванадцятёх утискованых европскых народів, підписав 26 октобра 1918 у Філаделфії Выголошіня незалежности. У своїм выступлїню перед підписанём Выголошіня підкреслив особитость угорьскых Русинів і їх одлишность од Українцїв, підкреслив тыж нетотожну історію обидвох народів, хоць допустив близкость їх языків (Šandor 1992, 202).

25 октобра 1918 в готелї Беллвю-Стретфорд у Філаделфії ся одбыла діскузія америцькых Русинів з Т.Г. Масаріком о можнім припоїню к Чехословакії, о статусї Русинів у нїй і о граніцї, котра бы ся так не стала вонкашнёв, але лем внуторнов - країньсков граніцёв. Т.Г. Масарік не відїв проблему в тім, же бы Русины не могли мати в новім штатї рівноправну позіцію, докінця гарантовану автономіёв русиньской теріторії. На основі Жатковічовых споминань, Масарік Русинам на тій стрїчі пообіцяв повну автономію (Žatkovič 1921, 5). О граніцях Жатковіч повів, же граніиї будуть становлены так, же Русины будуть спокійны. Можеме ся лем догадовати, же Масарік, обіцяючі Русинам автномію, выходив 3 представы з року 1915, закы Жатковіч відїв гарантовану спокійность Русинів тогды, кедь высше спомнянуты комітаты будуть частёв автономной Угрорусинії. То значіть, же Масарік не зробив ніч про то, жебы Жатковічови обяснив свою представу. Стало ся так аж в роцї 1919 на паріжскій міровій конференції.

Америцькы Русины на основі такого заключіня з порады у своїй пресї опубліковали Масарікове обіцяня і зачали інтензівну кампанію меджі краянами за припоїня теріторії угорьскых Русинів к будучому чехословацькому штату. Америцька народна рада Угро-Русинів засїдала 12 новембра 1918, жебы продіскутовала условія вступу до чехословацького штату. 3 діскусії была прията резолуція, в котрій окрем іншого точно становили теріторію автономной Русинії: Жебы Угро-Русины з найшыршыма самосправныма компетенціями, як штат на федератівній базї, припоїли ся ід Чехословацькій демократічній републіиї, за такого условія, же до нашой краӥны мусять належати вшыткы автохтонны угро-руськы комітаты (vsi originalno uhro-russki stolici - в оріліналї, П. Ш.): Спіш, Шаріш, Земплін, Абауай, Гемер, Бориод, Унг, Уsоча, Берег і Мараморош (Žatkovič 1921, 5). На другый день передав Жатковіч у Вашінгтонї резолуцію Масарікови, котрый проявив радость з того, же зъєдночіня Русинів і Чехословаків до єдного штату так швыдко проходить. Додав, же все $\epsilon$ то лем позіція Америцькой народной рады Угро-Русинів, котра 
бы могла быти на міровій конференції в Паріжу выставена похыбностям. Зато народна рада зачала організовати плебісціт меджі америцькыма Русинами, в котрім ся мали высловити за котрым штатоправным рішїнём стоять.

В плебісцітї зробленім з цїлём здобыти одповідь америцькых Русинів на вопрос, як рїшати штатоправны вопросы Русинії, ся высловило 1113 делегатів. 3 них за припоїня к ЧСР голосовало 732 (66,42\%), за припоїня к Україньскій републіці 320 (28,13\%), за незалежность 27 (2,43\%), за споїня з галічскыма і буковиньскыма Русинами 13 (1,18\%), за споїня з Россіёв 10 $(0,9 \%)$, за припоїня к Мадярьску $9(0,81 \%)$ делегатів а за споїня з Галічов 1 делегат (Позерай: Žatkovič 1921, 6; Šandor 1992, 204-205; Danko 1993, 178).

Плебісціт, хоць не репрезентовав волю вшыткых Русинів США, і так указовав релатівно репрезентатівный погляд на будучность Русинів дома. 66,42\% делегатів, котры были за чехословацькый штат, дало далшым актівітам Г. І. Жатковіча на хосен Чехословацькой алтернатівы легітімный характер.

Русины на домашній теріторії ся к Чехословакії голосили тыж аж як іншы штатотворны алтернатівы одпали. І в їх припадї доходило односно теріторіалных претензій к незгодам. Притім обидва бокы были приправлены тому другому дати максімалный простор і добры условія про їх народотворны актівіты і завершіня етноідентіфікачного процесу кедь Русины або Словаци ся стануть частёв штату того другого.

В русиньскім контекстї ся чехословацька алтернатіва обявила лем в представах пряшівской Карпаторуськой народной рады, што было і безпосереднёв реакціёв на процесы, котры навколо нёй главно в януарї 1919 проходили. 11 януара 1919 таке рїшіня передав Ваврови Шробарови, уповномоченому міністрови про справу Словакії, председа Карпаторуськой народной рады Антоній Бескид.

\section{Рік 1919 а припоїня Підкарпатьской Руси к Чехословакії}

Рік 1919 ся про Европу і про утискованы народы бывшой австро-угорьской монархії зачав надійно. Паріжска мірова конференція, котра ся зачала в януарї 1919, підпорила взник тзв. наступницькых штатів намісто утриманя інтегріты монархії, і на основі міровых договорів (Версайскый, Сенжерменьскый і Тріаноньскый) становила їх граніцї. Тот 
процес ся дотуляв Чехословакії а з нёв і вшыткых народностей, котры ся ставали єй обчанами, то значіть і Русинів.

Од зачатку міровой конференції приправлёвала чехословацька делегація окрем іншого і основны матеріалы на припоїня теріторій заселеных Русинами к чехословацькому штату. Але не ішло ту о теріторію северовыходной Словакії - о северны части Спішской, Шарішской і Земпліньской жупы, котры были до Чехословакії задїлены як інтегрална часть Словакії, але о теріторію пізнїшой Підкарпатьской Руси - то значіть о Ужску, Бережску, Угочску жупу і часть Мараморошской і Бач-бодрожской жупы.

Репрезентант Русинів северовыходной Словакії і председа Карпаторуськой народной рады Антоній Бескид мав по приходї до Паріжа, де одышов з ініціатівы Вавра Шробара і з повірінём чехословацькой влады і презідента Т.Г. Масаріка, в менї русиньского жытельства мав высловити ёго волю жыти в ЧСР. Подобну задачу мав Г. Жатковіч, котрый зачленїня теріторії Русинів до нового штату підпорив у менї америцькых Русинів. 13 фебруара 1919 створили тзв. Руську (Русиньску) комісію, котра уж выступала в менї вшыткых Русинів. Обидвоме представителї Русинів передали К. Крамаржови і Е. Бенешови резултаты плебісціту америцькых Русинів, протокол пряшівской Карпаторуськой народной рады із 7.1.1919 і копію меморандума свалявской Руськой народной рады, котрыма доказовали інтерес Русинів о зачленїня до ЧСР. Е. Бенеш тоты документы предложыв Найвысшій раді.

Зачленїня теріторії Русинів підтримав 27 фебруара 1919 Америчан Чарлс Сеймур, історик і председа австро-угорьского оддїлїня америцькой міровой комісії з аргументом, же кедь то так хотять самы Русины, то США не має ід тому ниякы претензіі.

Но в Празї іщі было побоёваня з позіції далшых русиньскых представителїв к чехословацькій алтернатіві. Зато Т.І. Масарік радив Жатковічови іти до Пряшова і Ужгорода, стрїтити ся з домашнїма русиньскыма представителями і підтримати їх позіцію за ЧСР. В марцу 1919 їм І.І. Жатковіч представив позіцію америцькых Русинів к ЧСР і здобыв їх згоду, жебы в Паріжу зробив далшы крокы на зачленїня їх теріторії до Чехословакії.

Выголошіня Мадярьской републікы рад (МРP) в марцу 1919 і наслїдна трансформація русиньской теріторії, котра іщі все была під мадярьсков справов, на теріторію МРР, хоць під тітулом автономной Руськой 
країны, ускорило рїшіня трёх найвпливнїшых руськых народных рад офіціално підпорити чехословацьку алтернатіву. Стало ся так 8 мая 1919 в Ужгородї, котрый у тім часї быв уж обсадженый чехословацькым войском. На сполочнім засїданю ужгородьской, пряшівской і хустьской руськой народной рады была створена Централна руська народна рада, котра ся высловила за ЧСР а свій програм сформуловала в 14-ёх пунктах. Їх автором быв Г. І. Жатковіч. ЦРНР в єднім із пунктів жадала, жебы ся новый штат называв Чесько-словацько-руська републіка, в далшых зась Русины жадали автономный статус Підкарпатьской Руси і ясне становлїня єй западной граніцї із Словакіёв; жебы Підкарпатьска Русь была справована міністром, котрого бы меновав презідент; окрем загранічной політікы, фінанцій і обраны мала вшытка законодарна і екзекутівна міць належати містным автономным органам; у спорных вопросах меджі ЧСР і Підкарпатьсков Русёв мала вырїшовати Сполочность народів (Švorc 2007, 54-55).

Вырїшіня о припоїню к ЧСР тлумачіла 112-членна делегація ЦРНР 23 мая 1919 в Празї міністрови внуторных дїл А. Швеглови і презідентови Масарікови. Так ся выповнило єдно з условій Т.Г. Масаріка, жебы ся за припоїня теріторій заселеных Русинами к Чехословакії офіціално высловили і самы Русины. Фактом є, же процес формованя повойновых штатів, то значіть і Чехословакії з теріторіёв Підкарпатьской Руси, быв уже на міровій конференції в кулоарах одобреный, а формално ся так стало якраз 23 мая 1919, коли Рада міністрів загранічных дїл на конференції прияла пропозіцію Е. Бенеша припоїти Підкарпатьску Русь к Чехословакії як єй автономну теріторію.

Чехословацька влада потім зробила першы крокы, жебы ся пропозіція стала і реалітов. В місяцях май - юл 1919 припоїня Підкарпатьской Руси к ЧСР іщі компліковала екзістенція Мадярьской републікы рад на теріторії Підкарпатьской Руси, но і обсаджіня єй южной і выходной части румуньскым войском. По падї МРР і діскусіях з Румуніёв была теріторія Підкарпатьской Руси поступно обсаджована чехословацькым войском а до платности ся ту дістала і чехословацька легіслатіва. Про теріторію Підкарпатьской Руси быв выменованый адміністратор, котрым ся став Ян Брейха, якый адміністровав Цівілну справу Підкарпатьской Руси, а влада выменовала Дочасну директорію автономной Підкарпатьской Руси (Др. Грігорій Жатковіч, Августин Волошин, Др. Юлій Бращайко, Др. Евґен Тороньскый, Др. Юлій Гаджега) як порадный орган. 
10 септембра 1919 быв в Сен-Жермен ен Лай підписаный міровый договор з Австріёв а ёго частёв ся став і мінорітный договор, подля котрого была Підкарпатьска Русь правоплатно причленена к Чехословакії.

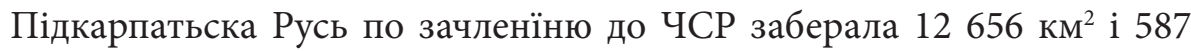
сел з 599808 жытелями. 3 них 372884 належало ід руській (русиньскій і україньскій) народности, 102144 ід мадярьскій, 80059 ід жыдівскій, 19737 ід чехословацькій (словацькій і чеській), 297 ід польскій а 10460 ід нїмецькій народности (Švorc 2007, 59).

Цїль припоїти Підкарпатьску Русь к Чехословакії ся de iure зреалізовав і з меджінародно-правного аспекту, но русиньска репрезентація не была спокійна. Усвідомила собі, же бівша часть їх жадостей не была зреалізована так, як собі то представлёвали. Ішло главно о западну граніцю із Словакіёв, котра мала характер країньской граніцї. Хоць становлена была як дочасна, но тота «дочасность» ся утримовала в прінціпі цїлый меджівойновый період, в котрім ся не реалізовала ани фактічна автономія Підкарпатьской Руси. То быв єден з найважнїшых факторів, детермінуючіх спокійность ці неспокійность Русинів з їх статусом в ЧСР.

\section{ЛITEPATУРA}

Danko, Osyp. 1993. «Rol zakarpatskoj emigracii v SŠA u vyrišenni doli Zakarpatt̉a v 1918-1919 rokach». Ukrajinski Karpaty.

Chymynec, Julian. 1983. Moji sposterežennja iz Zakarpatta. New York.

Kappeler, Andreas. 1994. Kleine Geschichte der Ukraine. München: C.H. Beck.

Kucík, Štefan, Švorc, Peter 2014. «Česko-slovenský zahraničný odboj v USA (1914-1918)

- slovenský pohlad». B: Slovenské a české krajanské hnutie v USA (do roku 1918).

Prešov: UNIVERSUM.

Magocsi, Paul Robert. 1994. Rusíni na Slovensku. Prešov: Rusínska obroda.

Magocsi, Paul Robert. 1999. Of the Making of Nationalities There is No End. Volume One: Carpatho-Rusyns in Europe and North America. New York: Columbia University Press.

Magočij, Paul Robert. 2006. Narod nizvidky. Iljustrovana istorija karpatorusyniv. Užgorod: Vydavnictvo V. Padjaka.

Polonska-Vasylenko, Natalija. 1988. Geschichte der Ukraine. Von den Anfänge bis 1923. München: Ukrainische Freie Universität.

Pop, Ivan. 2005. Déjiny Podkarpatské Rusi v datech. Praha: Libri.

Šandor, Vikentij. 1992. Zakarpatta. Istoryčno pravnyj narys vid IX. st. do 1920. New York. Švorc, Peter. 1991. Zrod republiky (Dobové dokumenty, spomienky a stanoviská 1914-1918). Košice: Slovo.

Švorc, Peter. 1996. Zakliata krajina. Podkarpatská Rus 1918-1964. Prešov: UNIVERSUM. 
Švorc, Peter. 1999. «Štátotvorné predstavy a snahy stredoeurópskych národov a realita po skončení prvej svetovej vojny (1918-1919)». B: Stredoeurópske národy na križovatkách novodobých dejín 1848-1918. Prešov-Bratislava-Wien: UNIVERSUM.

Švorc, Peter. 2003. Krajinská hranica medzi Slovenskom a Podkarpatskou Rusou (1919-1939). Prešov: UNIVERSUM.

Švorc, Peter. 2007. Zakletá zem. Podkarpatská Rus 1918-1946. Praha: Lidové noviny.

Švorc, Peter. 2012. «Prešov v prevrate 1918-1919 a po ňom». B: Velká doba a jej dôsledky. Prešov v 20. rokoch 20. storočia. Prešov: FF PU.

Tvoridlo, Mykola. 1922. «Z krasšich dnov na Podkarpattu». Narodnyj kalendar tovarystva Prosvyta na zvyčajnyj rok 1923.

VHA fond P. R., k. N. 1, R. 245, 1918-1920. Memorandum from the America Nacional Council of Uhro-Rusins, to his Excellency WOODROW WILSON, president of the United States of America. Praha: Vojenský historický archív (VHA). 